\title{
A NEW NAME FOR PODOCARPUS ROTUNDUS DE LAUB. (PODOCARPACEAE)
}

\author{
R. R. MILL
}

\begin{abstract}
Podocarpus rotundus de Laub. (1978), which has been used for an extant species of Podocarpus L'Hér. ex Pers. from the Philippines and Kalimantan, is an illegitimate name, being published later than its homonym P. rotundus Bocharn. (1960) that has been used for a Palaeocene fossil pollen morphospecies described from Sverdlovsk Oblast in the Urals (Russia). For the species from the Philippines and Kalimantan, the replacement name Podocarpus ramosii is here proposed.
\end{abstract}

Keywords. Extant Podocarpus, fossil Podocarpus, Kalimantan, new name, Philippines, Podocarpaceae.

\section{INTRODUCTION}

Podocarpus rotundus de Laub., originally described by de Laubenfels (1978), requires a replacement name, because its epithet was previously used by Bocharnikova (1960) for a Palaeocene morphospecies from Russia (fossil pollen). Notwithstanding that the latter might not be a Podocarpus at all, it was validly described as such, and thus the rules of priority require the replacement of de Laubenfels' later homonym unless the latter is conserved over Bocharnikova's epithet. An argument for conserving P. rotundus de Laub. over P. rotundus Bocharn. was published by Mill (2002) along with a formal conservation proposal. However, although the Committee for Fossil Plants voted narrowly in favour of that proposal (7:6 - Skog, 2003), the Committee for Spermatophyta has recently voted 6:9 against (Brummitt, 2006). The recommendation by the latter Committee was ratified at the Nomenclature Section of the XVII International Botanical Congress held in Vienna, 11-16 July 2005. Hence, the name Podocarpus rotundus de Laub., which has been used by several authors since it was originally published, including de Laubenfels (1985, 1988), Enright (1995), Farjon et al. (1993), Farjon (1998, 2001), Farjon \& Page (1999), Silba (1984, 1986), and Walter \& Gillett (1998), must now be replaced.

Podocarpus ramosii R.R.Mill, nom. nov. (Subgen. Foliolatus de Laub. sect. Gracilis de Laub.). - Podocarpus rotundus de Laub., Kalikasan 7(2): 136 (1978), nom. illegit. (Art. 53.1), non P. rotundus Bocharn. in I.M.Pokrovskaya \& N.K.Stel'mak, Trans. All-Soviet Sci.-Res. Inst. Minist. Geol. \& Petr. Conserv. U.S.S.R. n.s. 30: 362, pl. 2 
f. 4 (1960). - Type: 'Philippines, Luzon, Tayabas Prov., Mt. Banahao, M. Ramos 19581' (holo US n.v.; iso BM, K, L n.v. but colour photograph seen on Web).

The quotation is the type citation of $P$. rotundus de Laub. as given in his protologue. The Leiden isotype is actually labelled 'Laguna Prov., Mt. Banajao, Jan. 1913', and it is clear that the number 19581 is not in fact Ramos's own collection number but that allotted to the specimen by the Philippines Bureau of Science. Tayabas is a town in Laguna province, Luzon, and the current spelling for the name of the mountain where the type was collected is Mt. Banáhao (P. Wilkie, pers. comm., 27 October 2000). The type specimen was originally named as $P$. costalis Presl, and later determined as $P$. pilgeri by de Laubenfels (L, in sched.) before finally being described by him as the new species $P$. rotundus.

The replacement epithet commemorates Maximo Ramos (d. 1932), who made extensive collections in the Philippines, especially Luzon, including the type of $P$. rotundus de Laub. Bocharnikova based her earlier name (P. rotundus Bocharn.) upon a fossil (pollen) from Sverdlovsk Oblast, Russia, of Upper Palaeocene age. The holotype of her name is Sr. 1076/208 (UGU n.v.; illustrated in Bocharnikova, 1960: pl. 2 f. 4, reproduced in facsimile, with her complete protologue, in Kremp et al., 1962: sheet 92).

Podocarpus ramosii has a limited distribution in the Philippines and Indonesia (E Kalimantan: one record from Mt. Beratus near Balikpapan: de Laubenfels, 1988). It is a Red Data Book species (Walter \& Gillett, 1998 under P. rotundus), and its conservation status has been re-evaluated by the IUCN/SSC Conifer Specialist Group under the new IUCN criteria and confirmed as DD (M. Gardner, pers. comm., 16 May 2006) although in the Philippines it is being listed as Endangered (Defensor, 2005).

\section{ACKNOWLEDGEMENTS}

Thanks are due to Peter Wilkie (Royal Botanic Garden Edinburgh) for advice on modern Philippines geographical names, and to the reviewers of an earlier version of this paper who both strongly recommended that the existing name be proposed for conservation. The author greatly regrets that, after going through that process, the recent decision of the Committee for Spermatophyta has not recommended the sensible option of maintaining the current name of this threatened species.

\section{REFERENCES}

Bocharnikova, A. D. (1960). [Atlas of Upper Cretaceous, Paleocene and Eocene Spore-Pollen complexes of several regions of the U.S.S.R.; in Russian.] Trans. All-Soviet Sci.-Res. Inst. Minist. Geol. \& Petr. Conserv. U.S.S.R. n.s. 30. Leningrad. 575pp.

[Original not seen; facsimiles of new descriptions by Bocharnikova (1960) are reproduced in Kremp et al., Cat. Fossil Spores Pollen 16 (1962).]

Brummitt, R. K. (2006 ['2005']). Report of the Committee for Spermatophyta: 57.

Taxon 54: 1093-1103. 
Defensor, M. T. (2005). Establishing the National List of Threatened Philippine Plants and their Categories. www.pawb.gov.ph/posted_files/daoplants(asofnov22,2005)DEC-2.doc

Enright, N. J. (1995). Conifers of tropical Australasia. In: Enright, N. J. \& Hill, R. S. (eds) Ecology of the Southern Conifers, pp. 197-222. Melbourne: Melbourne University Press.

FARJON, A. (1998). World checklist and bibliography of conifers. Kew: Royal Botanic Gardens.

FARJON, A. (2001). World checklist and bibliography of conifers, 2nd edition. Kew: Royal Botanic Gardens.

Farjon, A. \& Page, C. N. (1999). Conifers. Status Survey and Conservation Action Plan. Gland, Switzerland \& Cambridge, UK: IUCN/SSC Conifer Specialist Group, IUCN.

Farjon, A., Page, C. N. \& Schellevis, N. (1993). A preliminary world list of threatened conifer taxa. Biodiversity and Conservation 2: 304-326.

Kremp, G. O. W., Ames, H. T. \& Kovar, A. J. (1962). Catalog of fossil spores and pollen. Volume 16. Mesozoic and Lower Tertiary spores and pollen. 169 sheets. University Park, PA: The Pennsylvania State University.

De Laubenfels, D. J. (1978). The taxonomy of Philippine Coniferae and Taxaceae. Kalikasan 7(2): 117-152.

De Laubenfels, D. J. (1985). A taxonomic revision of the genus Podocarpus. Blumea 30: 251-278.

de Laubenfels, D. J. (1988). Coniferales. In: Van Steenis, C. G. G. J. \& De Wilde, W. J. J. O. ('1986') Flora Malesiana 10(3). Dordrecht, Boston \& London: Kluwer Academic Publishers.

Mill, R. R. (2002). Proposal to conserve Podocarpus rotundus de Laub. (Recent Podocarpaceae) over Podocarpus rotundus Bocharn. (fossil Podocarpaceae). Taxon 51: 185-186.

Silba, J. (1984). An international census of the Coniferae, I. Phytologia Mem. 7. Plainfield, NJ: Harold N. Moldenke \& Alma L. Moldenke.

Silba, J. (1986). Encyclopaedia Coniferae. Phytologia Mem. 8. Corvallis, OR: Harold N. Moldenke \& Alma L. Moldenke.

Skog, J. E. (2003). Report of the Committee for Fossil Plants: 4. Taxon 52: 341.

Walter, K. S. \& Gillett, H. J. (eds) (1998). 1997 IUCN Red List of threatened plants. Compiled by the World Conservation Monitoring Centre. Gland, Switzerland \& Cambridge, UK: IUCN - The World Conservation Union. 